\title{
相対運動によるレーダー映像の歪について
}

\section{On the Distortion of Radar Display by Relative Motion}

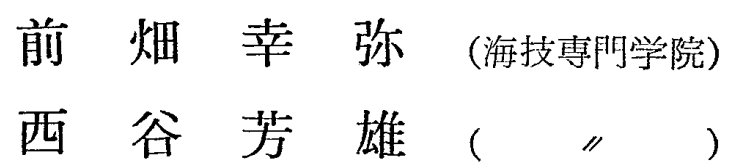

\begin{abstract}
Marine radar set at present uses the system of the P. P. I. presentation, which rotates continuously the scanner transmitting pulses in a narrow horizontal beamwidth, and which detects the targets in all directions while the set is in operation.

Some seconds, however, are required for each revolution of the scanner, and the ship being under way for the time, and distortion of radar display by relative motion is produced in a short range.

Nevertheless it has not been obvious, so we would research how much distortion will be produced by it. And taking this in a broad sense, we can consider that the change of a target's display between each revolution of a scanner is also the distortion.

Some photographs are shown here, indicating these distortions described previously.

We conclude that about 15 r.p.m. is the minimum speed of a scanner's rotation for the high speed vessel. Because the higher the speed of a vessel and the lower the one of a scanner's rotation, the larger is the distorting tendency.
\end{abstract}

\section{1. 緒言}

レーダー映像の歪に関しては、次にあげるようにいろいろ考えられる。すなちわ、イ．物標ま での距離がレーダー水平線よりも遠くて、水平線下に電波の届かない部分があつてての部分だけ 探知されない場合、口．地势的に反射強度が十分でなく探知されにくい場合、八．電波のビーム ウによる映像拡大効果によるものを考光た場合、二，船体傾斜によつて方位が歪む場合 ${ }^{1} 、$ 小。

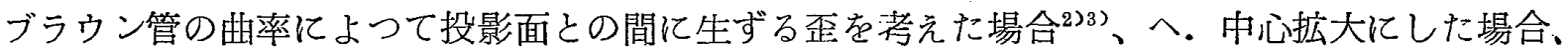
ト．調整が不良な場合等である。しかしてれらの歪については、今まで既に明らかにされてい る。

現在の船舶用レーダーは、一方向にパルス波を出しながらスキャナーが回転し、全方向の物標 を探知する P P I 方式である。スキャナーは回転するのに若干の時間を要し、この閒に船は航走 しているので相対運動によつて歪を生ずるのであるが、このととについてはいまだに明らかにさ れていない。そこでわれわれは相対運動によつてどの程度の歪を生ずるかを解明せんとした。

また船が航走中、スキャナーの各走查でとに、映像はその位置を変えるが、一回転でとに映像 は飛び石状になるので、とれも広義に解釈すれば歪と考えられる。との種の歪は記憶管の装置と 
多少関連のあるものといえるので、との奏験も紹介する。

今回幸いにも日本郵船所属の各船に便乗し、レーダ一映像を撮影する機会を得たので、ここに 上記の歪について報告する次第である。

\section{2. 方 位 $の$ 歪}

いま船がレーダーを作動して航行中、点 $\mathrm{O}$ において船首方向を走查したとすれば、物標 $\mathrm{T} か ゙$ 探
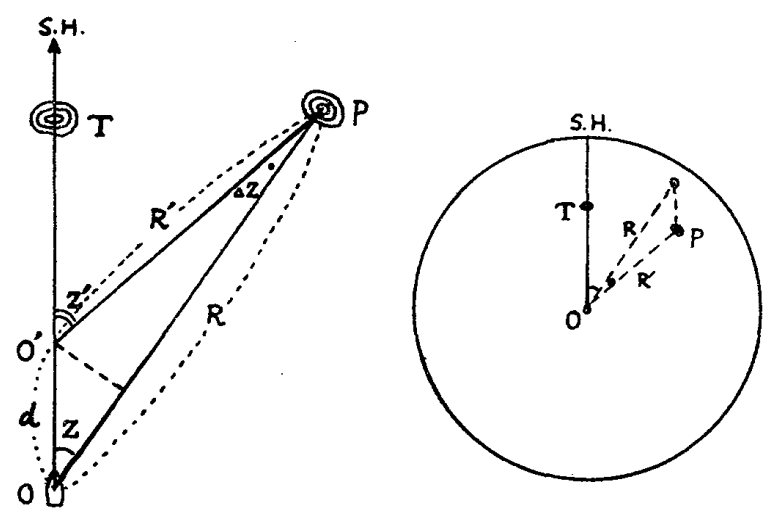

Fig. 1 的されCRT上に映像が認められる。しかし レーダー電波は水平ビームが約 $1 \sim 2$ 度とい う鋭い指向性をもつたものであるから、物標 $\mathrm{P}$ はまだ探知されていない。スキヤナーが船 首方向からPの方向に回転を続ける間、船は 点Oから点 $\mathrm{O}^{\prime}$ まで距離 $d$ を航走するが、点 $\mathrm{O}^{\prime}$ 亿達して物標 $\mathrm{P}$ を走查したとき、はじめて 物標Pが C R T.上に映像として認められる。 したがつてレーダーによつて測定される物標 $\mathrm{P}$ までの方位および距離は、 $Z$ および $R$ では

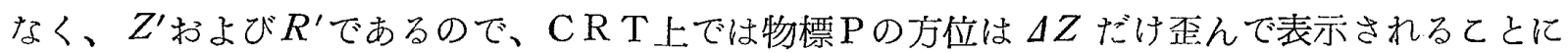
なるのである。

Fig. 1 において $\triangle \mathrm{OPO}$ 亿ついては次の関係がある。すなわち

$$
\frac{d}{\sin \Delta Z}=\frac{R}{\sin (Z+\Delta Z)}
$$

上式を解き、 $\Delta Z$ が微小であるため、 $\sin \Delta Z \fallingdotseq$ $\Delta Z, \cos \Delta Z \fallingdotseq 1$ と見なせるから、次式が得ら れる。

$$
\Delta Z=\frac{d \sin Z}{R-d \cos Z}
$$

$d$ はスキャナーが船首方向から物標 $\mathrm{P}$ 亿向く までに、船が航走した距離であるから、次式に 上つて求めるととができる。

$$
\begin{aligned}
d & =\frac{1852 v}{60 \times 60} \cdot \frac{60}{n} \cdot \frac{Z^{\prime}}{360} \\
& =0.0857 v Z^{\prime} / n
\end{aligned}
$$

ことに船の速力を $v$ ノツトで表わし、スキヤ ナ一回転数を $n$ r.p.m.とする。 $Z^{\prime}-Z=\Delta Z$ の僅かな角度だけスキヤナーが回転する間に、 船が航走する距離は僅かで無視することができ るので、上式 $d$ は次式で表わせる。

$$
d=0.0857 v Z / n \quad(m)
$$

(2)式を(1)式に代入して、度数で表わすて とにすれば、次のようになる。

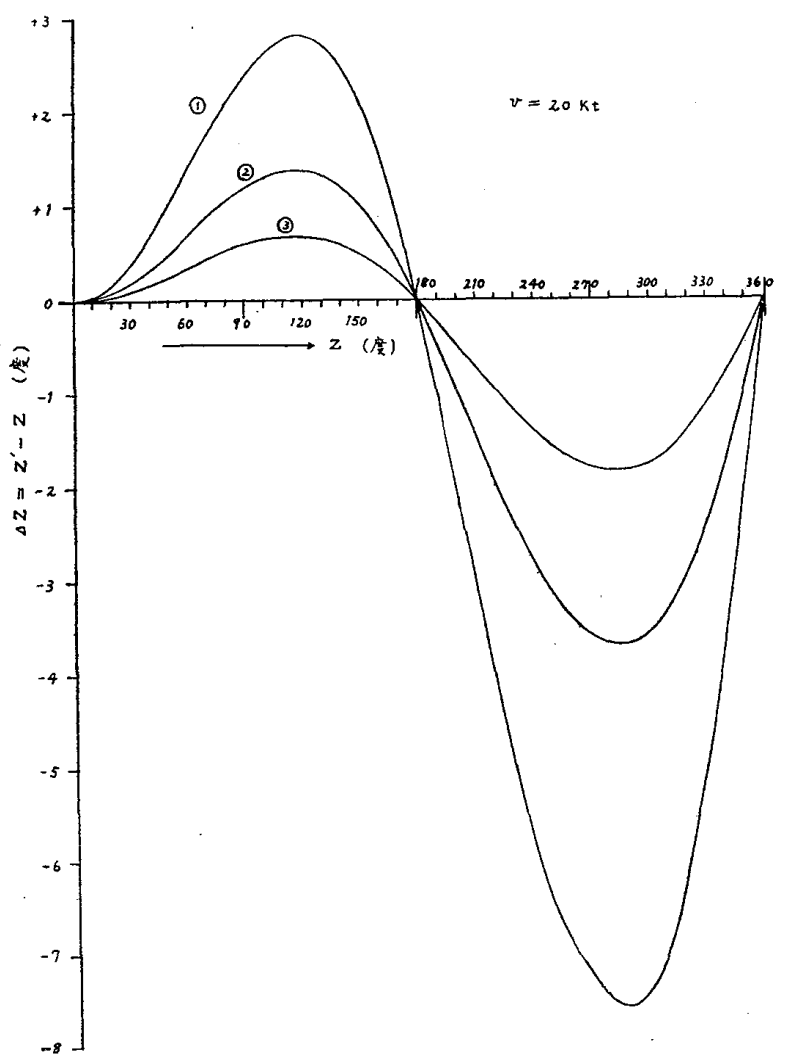

Fig. 2 


$$
\Delta Z^{\circ}=57.3^{\circ} \times \frac{0.0857 v Z \sin Z}{R n-0.0857 v Z \cos Z}
$$

(3) 式において、 $v=20$ ノツトとした場合、方位 $Z$ と方位の㱞 $\Delta Z$ との関係を示せば、Fig. 2のようになる。ただし Fig. 2 そおける曲線(1)，(2)，(3)は、スキャナー回転数と距離との間に おいて次の関係を有する。

Table 1

Fig. 2 の曲線にお汀る空中線回転数 $(n)$ と距離 $(R)$ との関係

\begin{tabular}{|c|c|c|c|c|}
\hline $\begin{array}{l}\text { 曲線番号 } \\
\text { 空中線回転数 } \\
(n)\end{array}$ & 8 r. p. m. & 16 r.p. m. & 24 r.p. m. & 32 r.p. m. \\
\hline (1) & $1 / 4$ 浬 & $1 / 8$ 浬 & $1 / 12$ 浬 & $1 / 16$ 浬 \\
\hline (2) & $1 / 2 "$ & $1 / 4 "$ & $1 / 6 \quad " 1$ & $1 / 8 \quad " \prime$ \\
\hline (3) & 111 & $1 / 2 \prime \prime$ & $1 / 3 \quad \prime \prime$ & $1 / 4 \quad 1 /$ \\
\hline
\end{tabular}

$\Delta Z$ の大きくなるのは、(3) 式および Table 1 より分るように、スキャナー回転数の小さい ときである。また物標までの距離 $R$ が小さく、速力 $v$ が大きいときである。しかも $Z$ が船首方向

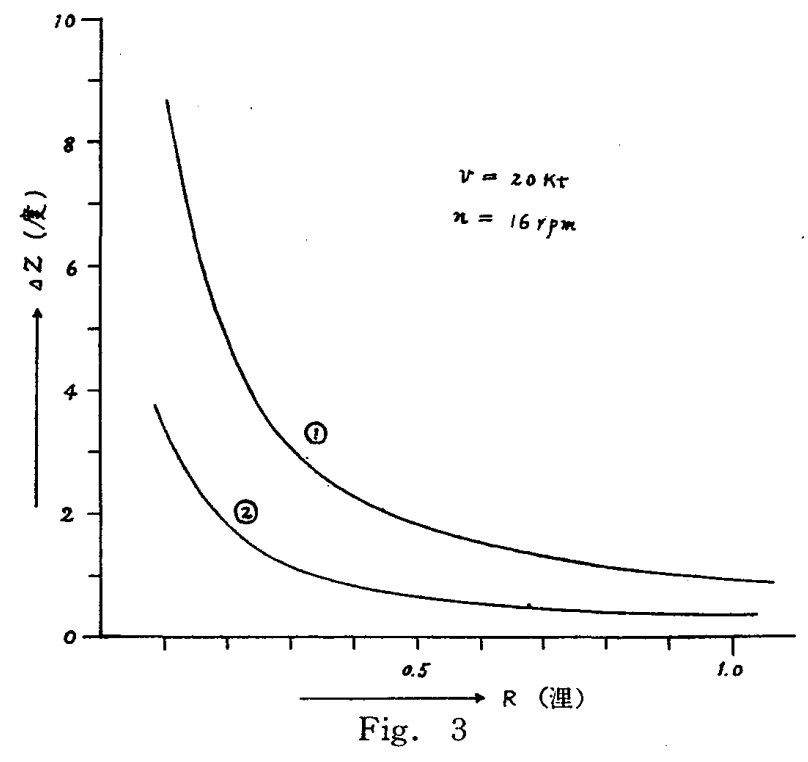

$\Delta R=R^{\prime}-\left(R^{\prime} \cos \Delta Z+d \cos Z\right)$

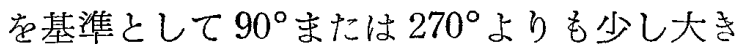
な值をとるとき $\Delta Z$ は極大值を示すが、 $Z$ が 後者の值のとき最大值となる。

次に $v=20$ ノツト, $n=16 \mathrm{r} . \mathrm{p} . \mathrm{m}$. の場合 の距離と方位の歪の極大值との関係を Fig. 3 に示す。曲線(1)，(2)はとに距離に対して方 位の疍の極大值を示すが, (2)は $90^{\circ}$ 付近のも ので、(1)は $279^{\circ}$ 付近の最大值である。

\section{3. 距 離 の 歪}

Fig. 1 亿おいて、物標 $\mathrm{P}$ 距離はRではな く $R^{\prime}$ として測定されることは、先に述べた 通りであるが、距離の歪は $\Delta R=R^{\prime}-R$ で求 められるから、

となるが、 $\Delta Z$ は微小で、 $\cos Z \fallingdotseq 1$ であるからら、次のように表わせる。

$$
\Delta R=-d \cos Z
$$

上式に（2）を代入すれば、

$$
\Delta R=-0.0857 \frac{v Z \cos Z}{n}
$$

（4）式において、 $v=20$ ノット， $n=8$ およ゙ 16 r.p.m. としたときの方位と距離の歪との 関係を示せば Fig.4のようになる。

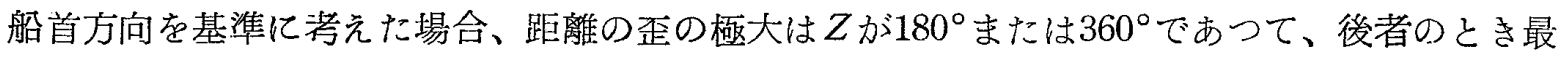
大值となる。

上に述べた方位の歪わよび唯離の歪は、同一の船について考光た場合、スキャナ一の回転数 $n$ 


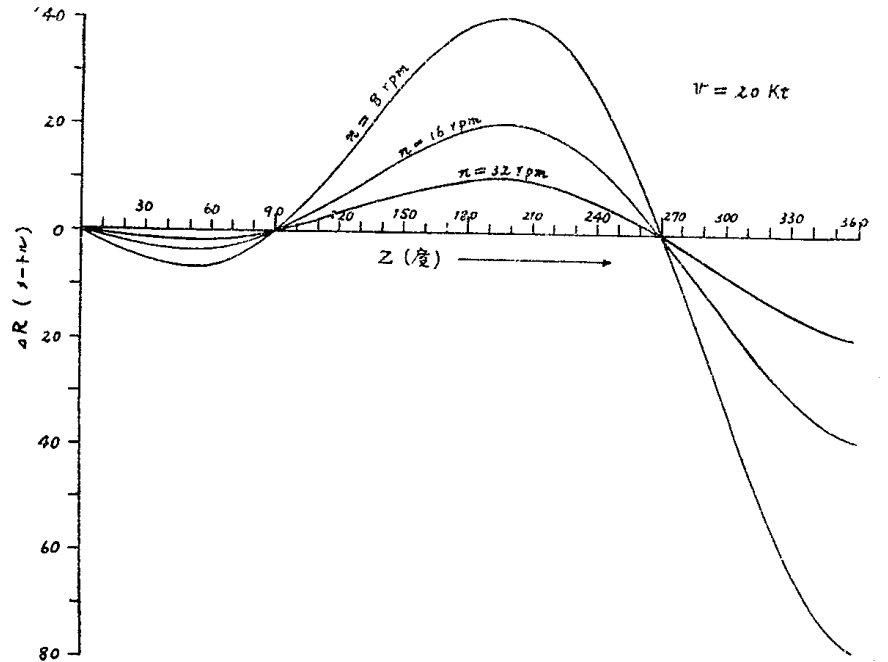

Fig 4

の大きいほど、霍が少亦いとい兄ので ある。ただしパルス繰返周波数、有效掃 引数、限界信昂值、パルス打よび磁電 管の寿命は互いに密接な関係があるの でタ、むやみにスキャナ一の回転数だけ を增加することはできない。また暴風下 でもスキャナ一が回転できるだけのドラ イブ・モーターの十分なトルクき考慮さ れなけ虬ばなら热い。次に日本、アメリ カおよびイギリスにおけるレーダーの中 加ら、映像面直柊12インチ以上の大型船 用レーダーの空中線回軽数だけ在あげる と、次の Table 2 の通りである。

Table 2

\begin{tabular}{|c|c|c|c|c|c|}
\hline 製造会社名 & $\begin{array}{c}\text { 油 霞 気 } \\
\text { Raytheon }\end{array}$ & R C A & $\begin{array}{c}\text { 三 } \\
\text { Westing House }\end{array}$ & $\begin{array}{c}\text { 東京計器 } \\
\text { Sperry }\end{array}$ & 日本無線 \\
\hline $\begin{array}{c}\text { 空中線回転数 } \\
\text { (r.p.m.) }\end{array}$ & 7 & $8.5 \sim 10$ & 14 & 15 & 16 \\
\hline 協立電波 & $\begin{array}{l}\text { 安立雷波 } \\
\text { 苯洋通信機 }\end{array}$ & Decca & Marconi & Kelvin-Hughes & Cossor \\
\hline 18 & 20 & 24 & 25 & 30 & 33 \\
\hline
\end{tabular}

\section{4. 映像写真による歪の検討}

筆者は日本郵船埼玉丸の神戸 / 八幡間の瀬戸内海航海に便乗し、先に述べた方位の罣抢よび距 離の奀に関して映像写真撮影による実験を行なつた。本実験には高速船の埼玉丸を選定し、鍋自 水道および早鞆瀬戸その他の各所において映像を連続的に撮影した。

埼玉丸レーダーの性能のうち、必要な項目をあげれば次の通りである。

埼玉丸レーダ一要目表

\begin{tabular}{|c|c|c|c|c|c|c|}
\hline 型 式 & 周 波 数 & パルスウ & 距離分解能 & 方位分解能 & 空中線回転数 & 真方装装 \\
\hline $\begin{array}{l}\text { 東京計器 } \\
\text { MK-2 DO }\end{array}$ & $9375 \pm 45 \mathrm{Mc}$ & $\left|\begin{array}{l}\text { 近距離 } 0.1 \mu \mathrm{s} \\
\text { 遠距離 } 0.4 \mu \mathrm{s}\end{array}\right|$ & 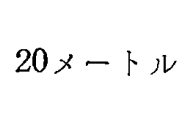 & 1. 0 度 & 15r.p. m. & あ \\
\hline
\end{tabular}

海図と映像との比較検討の前に、先ず撮影した各映像を適当な等しい大きさに引伸ばす。Fig. $5 \sim 8$ (a) はすべて1浬レンジを使用中のものであるが、これるには固定距離目盛が入つていな いので、他の 1 浬レンジ使用中の映像で、しかも固定距離目盛の入つたものを前の映像と等しい 大きさに引伸ばし、中央の 0.5 浬の固定距離目盛の半径の長さを測定する。次に海図を撮影した フイルムによつて海図の 0.5 浬を、先に測つた映像の 0.5 浬の半径の長さに等しく引伸ばす。乙 うするととによつて 0.5 浬の長さは両者とも等しくすることができるので、12インチCRTの曲 


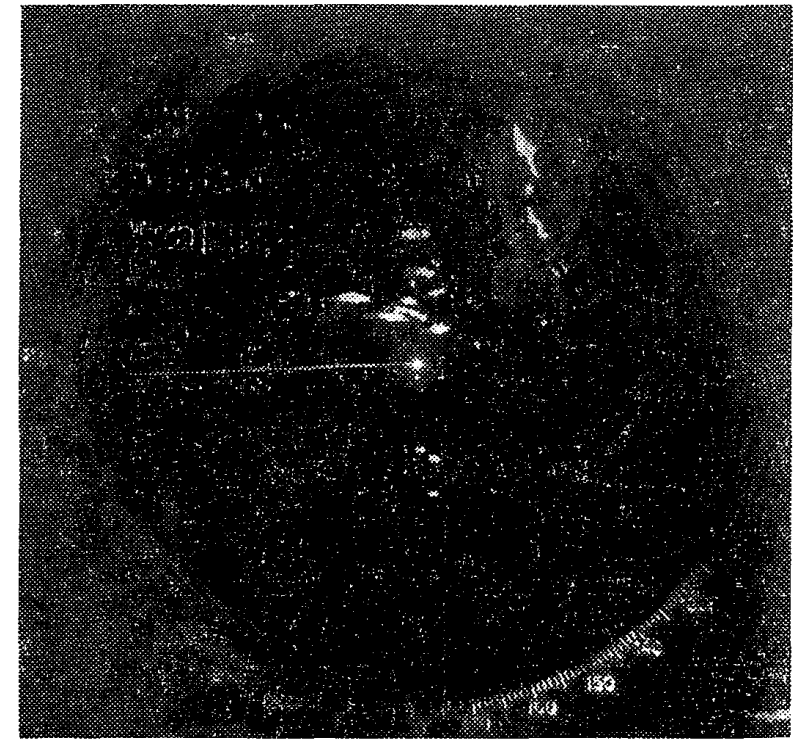

Fig. 5 (a)

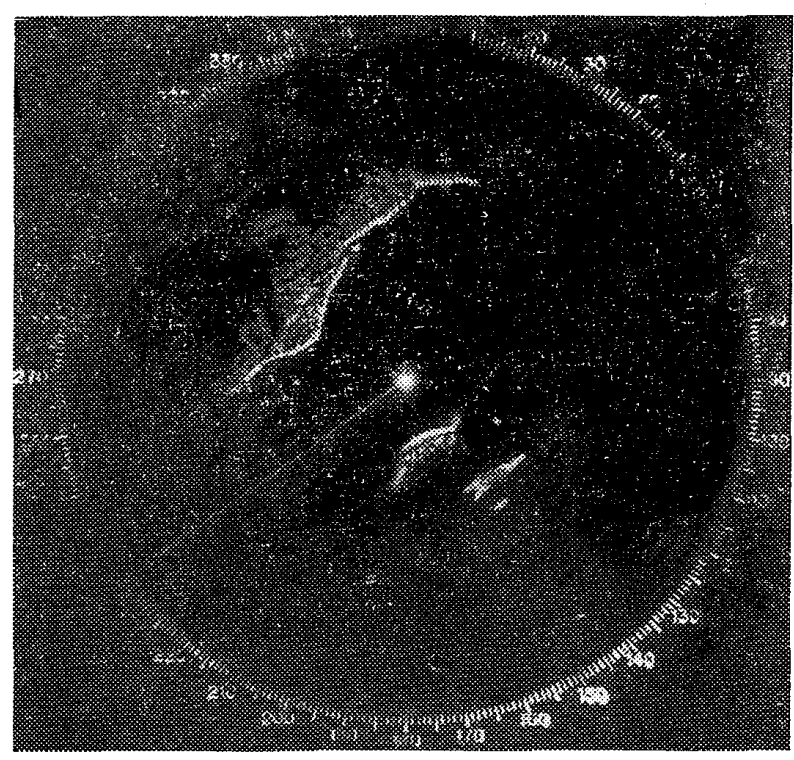

Fig. 6 (a)

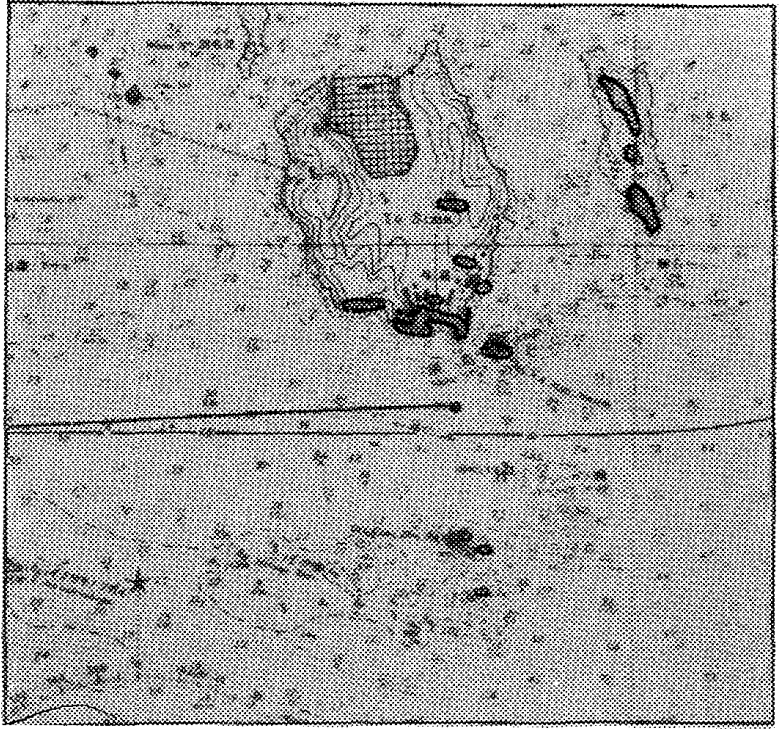

Fig. 5 (b)

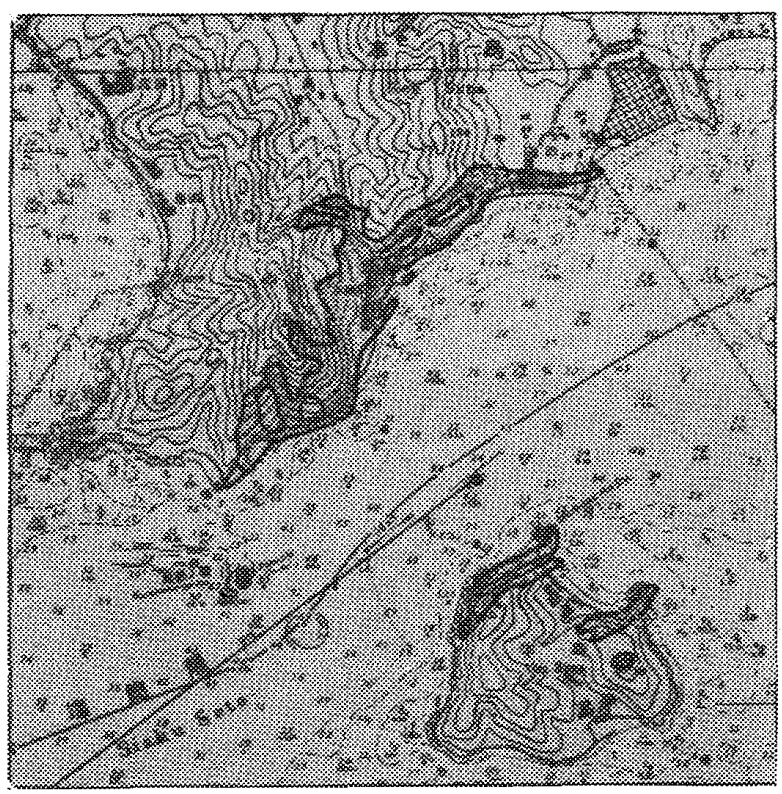

Fig. 6 (b)

率による歪は周井において甚だしいから、周囲付近では一致しないが、0.5浬までは曲率の影響 が殆んどなく、また緯度 1 の の長さを 1852 メートルとしても緯度が異なるための差は問題とする に足らず、映像と海図とを一致させることができるのである。Fig. 5〜8（a）の比較検討に必要 な部分は、すべて 0.5 浬までの範囲に含まれているので、このような手続きによつて曲率の影響 を無視しても差支えないものとするととができる。映像および海図の引伸ばしには、両方とも卜 レーシング用印画紙（例えば三菱 $\mathrm{CH}$-T）を使用した。

次に両者を重ね合わせ海図投影器上において、下からの光線を利用して、海図を引伸ばした印 画紙に映像のアウトラインをとり映像部分に着色を施した。

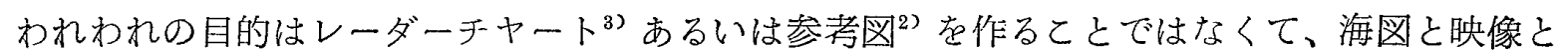
の間の歪を検討するのが目的であるので、先に述べたような方法によつた。Fig. 5〜8 (b) はこ のような手続きによつて作製したものの必要な一部分を掲げてある。 


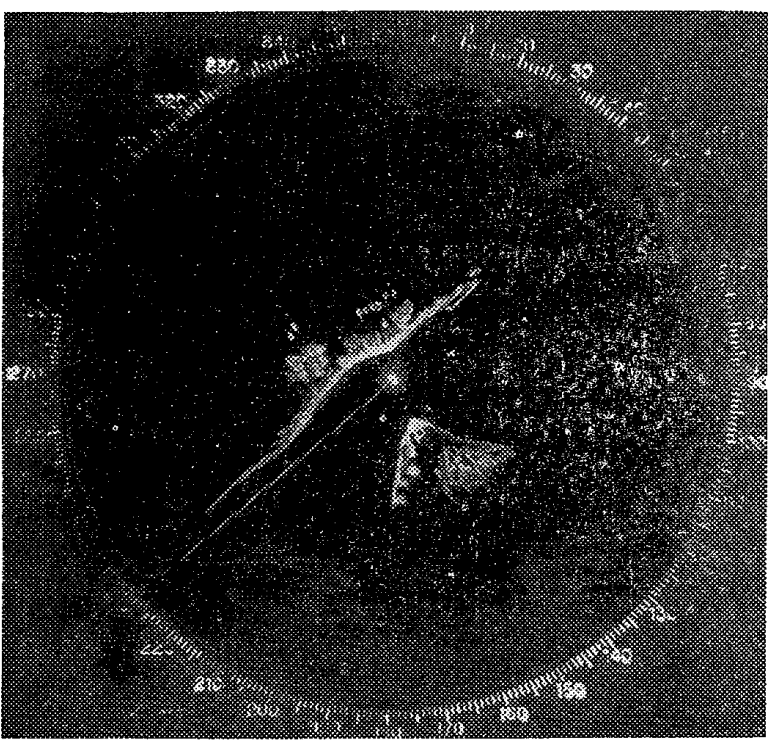

Fig. 7 (a)

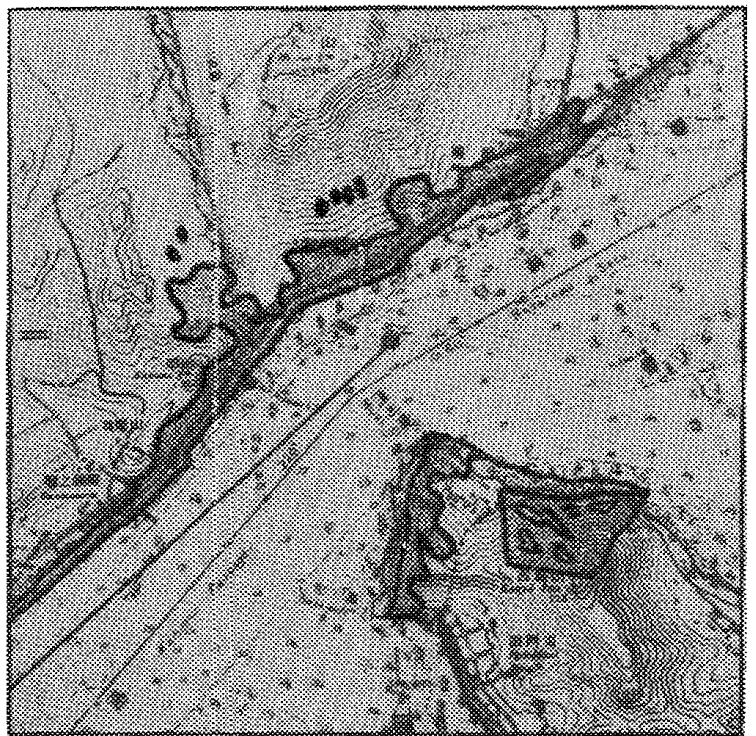

Fig. 7 (b)

さて、両者の比較検討であるが、方位の歪の計算と実験とによる結果を次の Table 3 に示す。 ただし歪の顕著に現われる $Z=270^{\circ}$ 付近の映像で、しかるはつきりと識別のできるものを選定 した。また $Z=90^{\circ}$ 付近で識別の容易なむの、すなわち Fig. 5（a）の鍋島灯台、Fig. 6（a） のカシノ鼻、Fig. 7 (a) の壇，浦鼻、Fig. 8（a）の弟子待鼻などは歪が少いのでここには除外 してある。

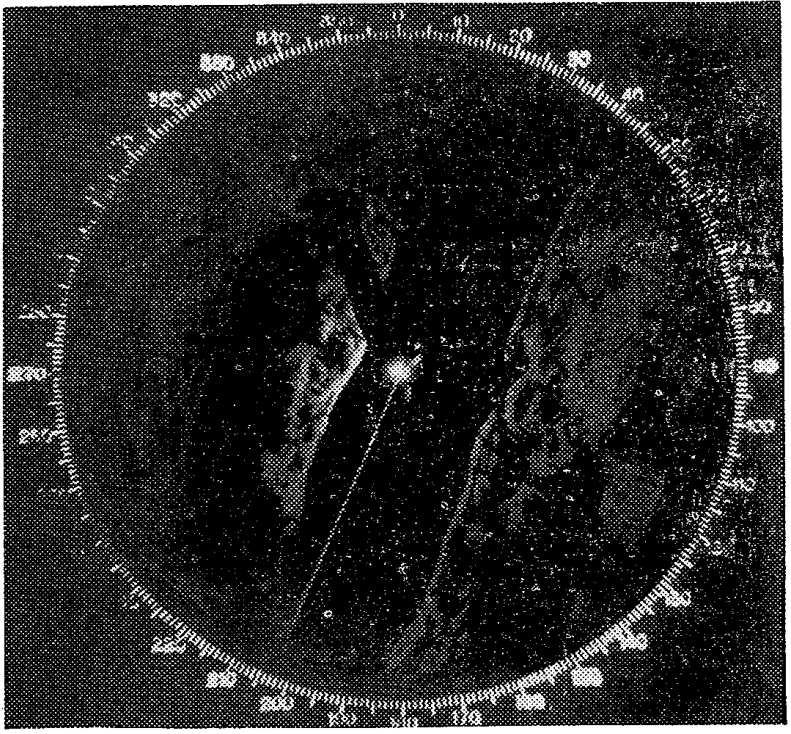

Fig. 8 (a)

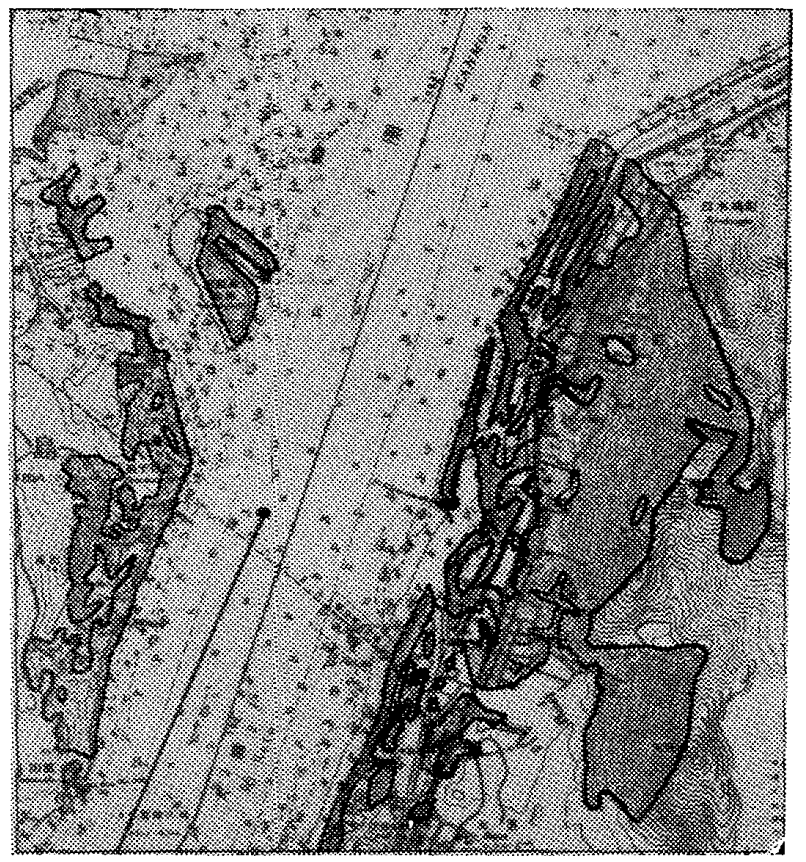

Fig. 8 (b)

一般に方位誤差の生ずる原因はいろいろ考光られるが、測定上の䜋差についていえば、どの物 標か確認したときでも方位カーソルがその映像から少し外れると請差を生ずるが、中心伒いと きは特にそうである。まして海岸線の特長からいつて識別の困難なところでは方位の測定には特 に慎重を要する。この理由から上記のように三ツ子島灯台、牛島灯標、門司埼灯標および白埼 防波堤灯台の方位を測定して計算值と実験值とを比較検討したのである。 
Table 3

\begin{tabular}{|c|c|c|c|}
\hline \multirow{2}{*}{ 物 標 名 } & \multirow{2}{*}{$\begin{array}{c}\text { 通過時実速力 } \\
(ノ ッ ト)\end{array}$} & 方 位 の & $(\Delta \mathbf{Z})$ \\
\hline & & 計 算 值 (度) & 実験 值 (度) \\
\hline 三ツ子島灯台 & 21 & -3.0 & -3.5 \\
\hline 牛 島 灯 標 & 21 & -3.9 & -3.5 \\
\hline 門 司 埼 灯 標 & 17 & -2.2 & -4.0 \\
\hline 白木埼防波堤灯台 & 17 & -1.9 & -3.0 \\
\hline
\end{tabular}

\section{5・空中線の各走查間における映像の歪}

いま船首方向に固定物標があると仮定し、船首方向を基準に考えた場合、物標の映像は C R T 上を相対運動を行なつて次々と本船に近づくことになる。このとき空中線が物標を走查した瞬間 に映像が現われ、CR Tの残光性によつてての位置に次の走查まで映像は静止したまま認められ る。故にこの間距離の歪を生じているととになるが、速力を 20 ノット、空中線回転数を 15 r.p.m. とした場合、（4）式によつて距離の歪は約 $41 \mathrm{~m}$ と計算される。換言すれば 12 インチ C R T上を 1 浬レンジ使用中映像が $3.3 \mathrm{~mm}$ ずつ移動することになる。

また船首方向以外の方向にある固定物標のときは、その物標の方向を基準に考えた場合、ある 走查のときから次の走查のときまで、距離の歪と方位の歪とを同時に生じていると考えられる。

次に移動物標の場合でも、本船との間の相対針路および相対速力を考えねばならない点は、固 定物標の場合と多少異なるが、各走查間に距離の歪や方位の歪が生じているものと考えられる点 は全く同じである。例えば相対速力 40 ハット、相対針路 $180^{\circ}$ 、空中線回転数 $15 \mathrm{r} . \mathrm{p} . \mathrm{m}$. の場合、 距離の歪は約 $82 \mathrm{~m}$ であるが、これは 1 浬レンジ使用中 C R T 上で約 $6.6 \mathrm{~mm}$ 亿相当する移動量で ある。

このように歪を広義に解橎すれば、各走查間における間断のない物標の移動も歪として考える ことができるが、レーダー映像の撮影に祭して、レンズを開放して連続露出を行なえば、歪の量 が分ると同時に他船の航跡が分るのである。Fig. 9〜12 はこのような考光方にもとづいて、連続 露出法によつてレーダー映像をを撮影したものである。

\section{6. 連続露出による写真に関する考察}

連続露出法によつてレーダ一映像を撮影すれば、海上が比較的平穏な場合には相当な時間露出 を与えるととができる。すなわち海面反射などの有害なものはＳＴＣを十分にきかせるととによ つて防止することができる。

このことは記憶装置をもつたレーダーを使用した場合に、海面反射のみならず雨雪の反射を防 此する上に扔いて、これらの有害反射が相当な程度まで防止するてとができるというように考え られる。記憶装置によつて他船などのように継続的に反射されてくる受信信号は記憶されるが、 海面反射などのような断片的な受信信号は記憶されないような特殊な装置が考案うされているが てのような特殊回路が何かの都合で使用されない場合なぞ、現在のS T C （またはログ感度調整 器）によるだけでも、海面反射防止には相当な程度まで有効であるといえる。ただし S T C は、 
このような目的に使用するには、段階的に変化させるものでなく、連続的に変化させるととので きるりのであるととが望ましい。何となれ隹限界信号值以下にならない程度で、しかも海面反射 を十分に防止できる程度に、自由にS TCを加減するととができるようにしておけばよいからで ある。

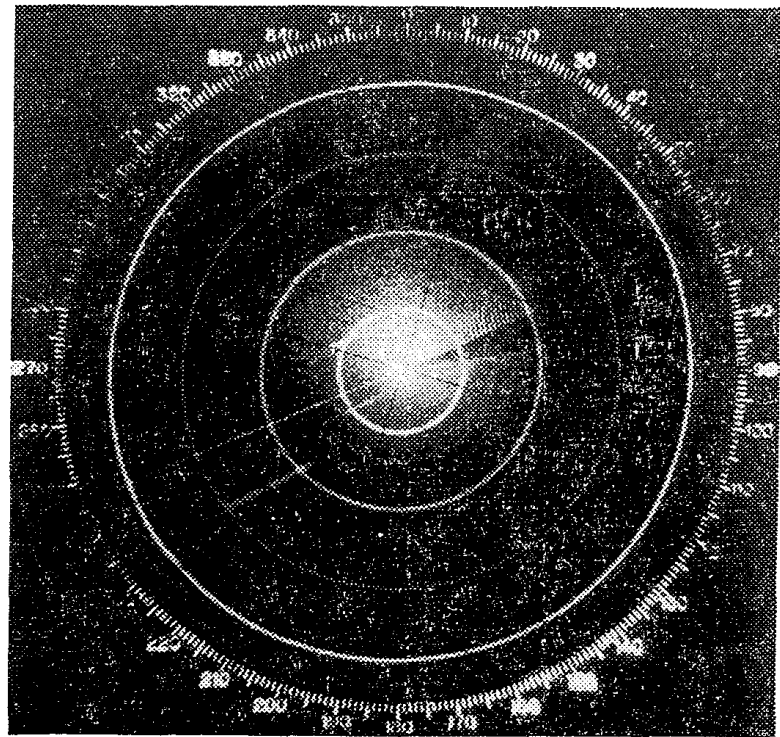

埼玉丸にて撮影 周波数 $9375 \pm 45 \mathrm{Mc}$

距離分解能 $20 x$-トル 方位分解能 1 度 空中線回転数 15 r.p.m.

Fig. 9

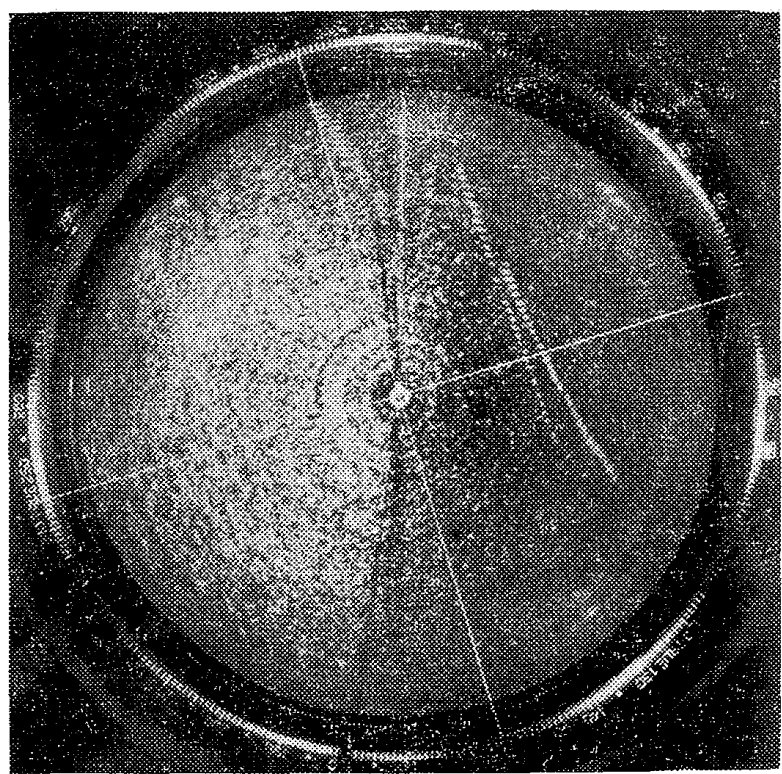

佐賀丸にて撮影 周波数 $9375 \pm 45 \mathrm{Mc}$
距離分解能 80 メートル 方位分解能 1.2 度 空中線回転数 7 r.p.m.

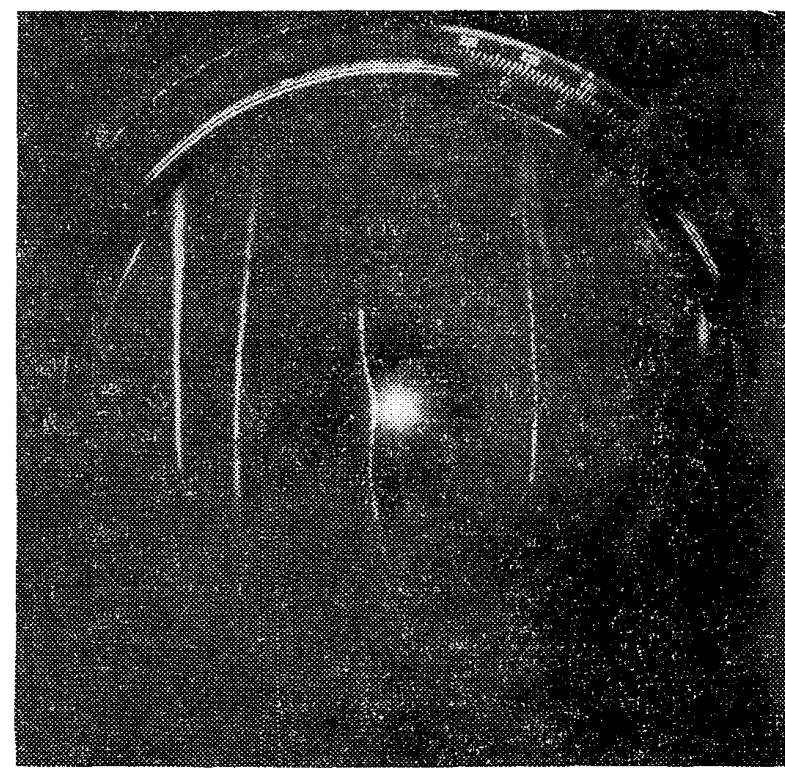

駿河丸にて撮影 周波数 $9375 \pm 45 \mathrm{Mc}$ 方位方解能 1.5 度 空中線回転数 18 r.p.m. Fig. 10

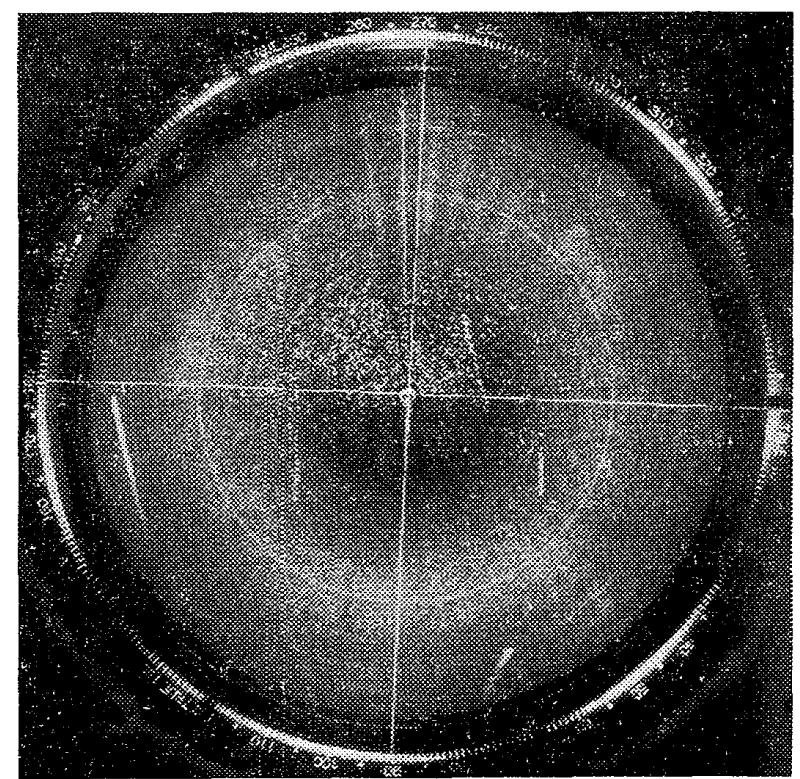

佐賀丸にて撮影 (要目 Fig. 11 に同じ)

Fig. 12 Fig. 11

さて Fig. 9 は Anti-Cltter 3 の場合であるが、S T C は段階的なため初心者の操作には便利 であるが、先に述べたように自由にＳTCをきかせるというととは困難である。なお $230^{\circ}$ 方向の 
点状の映像はくれない丸（総トン数約 2,800 トン、客船）の航跡であつて、相対速力が約 38 ノッ トの場合である。また本船の船尾方向には本船の波が探知されている。

Fig. 10 および Fig. 12 はS TCが十分にきいており、Fig. 11 にくらべて海面反射が少い。 Fig. 10 で右側か風上で、左側が風下であるが、風下側の海面反射は相当に有害で、風下側を通 る船の航䟢海面反射によつて消されるおそれがある。

Fig. 10 の左端の航跡は約 7,000トンの貨物船、左から三番目は釣舟の航跡で、本船との相対 速力は約27ノットである。またこの三番目の航跡か映像の中心付近で中心に多少接近しているの は、変針の影響でなくて Non linearity の影響であると筆者も判断するところである。このよ うな調整の不良がある場合、個々に測定した距離に䛊差がなくても、距離が linear scaleにな つていないので、海図と比較したとき映像はその部分が歪んで現われる。とのような場合には海 図と映像とを合わせることは困難になると思われる。

\section{7. 結 論}

上上のととから次のとおり綕論する。

（1）相対運動による映像の㑮を小さくすることのみを考えた場合、スキヤナー回転数は近距 離レンジに扔いては早いほどよいといえる。しかし他の条件もあわせて考光るとスキヤナー回転 数のみをむやみに早くすろてとはできないから、20ノット前後の高速船では約 15 r.p.m. 程度が 最小限の回転数といえる。

（2）船の速力が遅いほど同様に歪が小さいといえる。したがつて近距離のレーダーチャート を作製ずるような場合には、船の速力を微速もしくは停止して行なうととが必要である。

（3）高速船で海図比較装置を用いるときは、相対運動による映像の歪を考慮しておかなけれ ばならない。

（4）記憶装置は他船の釬路および速力を判断するのに有效であるが、Non linearity の影響 は針路に誤差を及ばすととになるので、 linearity の調整は正しくなされておらなければならな い。

終りに本稿在進めるに当つて、種々御指導を賜わりました海技専門学院長伊藤文雄教授、また 実験に御協力を賜わりました日本郵船株式会社取締役海務部辰片桐義礼氏、同神戸支店在勤海務 監督宮原勇氏、同副監督轟正氏、同海務課長志村啓氏、および当時の駿河丸船長吉越元氏、埼玉 丸船長丸尾卓志氏、佐賀丸船長永田八束氏ならびに各船航海士の諸氏に深䓁の謝意を表する次第 であります。

\section{参考 交 献}

1）庄司和民：船の傾斜によるレーダーの方仙愦差について 日本航海学会誌第 7 号

Cady, Karelitz, Turner: Radar scanners and randomes M. I. T. Radiation Laboratory p. $463-$ p. 472

2）松本・市瀬・樽美・前田：内海レーダ一航法参考図についで 日本航海学会誌第 21 号

3) 巻島・中西：レーダ像と海岸地形の対応について 日本航海学会誌第 21 号

4) Louis N. Ridenour: Radar system engineering M. I. T. Radiation Laboratory p. 35-p. 47

5）落合・茂在：レーダの理論と実際 p. $320-$ p. 323 